\title{
Bibles and Books: Bohemia and Hungary
}

\author{
Pál Ács, Howard Louthan
}

\section{Introduction}

Though the connection between religious reform and the printing press remains a topic of considerable debate, few question the significance and impact of print on the growth and spread of the Reformation across Central Europe. Indeed, the region has an especially rich literary heritage for this period. Elites eagerly followed developments in the west and were avid consumers of religious literature. In some parts of Central Europe there was a near mania for a figure such as Desiderius Erasmus. The first translation of The Praise of Folly into a vernacular was Czech. The first printed book in Hungarian was a translation of the Epistles of Paul, following an Erasmian model. In Poland there was a veritable cult of Erasmus and a concerted if ultimately ineffectual campaign to entice him to settle in Cracow. The literary history of Central Europe, though, is often encased in interpretive frameworks that are primarily nationalist. The Poles, the Czechs, and the Hungarians all have their own histories closely connected to the evolution of their respective languages. Against this backdrop it is important to remember the trans-national character of this region's literary cultures. It was a Franconian printer in Cracow who produced the first book with Cyrillic characters. The first extant book in Hungarian appeared in Cracow. Prague was not only a critical centre for the production of Czech Bibles but also home to the first translations of Scripture into both Sorbian and Belarusian. There was no single print culture for Bohemia. Printers busily produced books in Czech, Latin, German, and Hebrew.

There is much to explore were we to present a general survey and broad overview of this region's literary cultures. There are the efforts of the Slovenian reformer Primus Truber (Truber's career is discussed in Chapter 6) who collaborated with a Carinthian nobleman in a Swabian village to produce Bibles, hymnals, catechisms, and even a translation of the Augsburg Confession in Slovenian and Croatian using Latin, Cyrillic, and Glagolitic scripts. ${ }^{1}$ In Austria there is the often forgotten contribution made by the Lutheran David Chytraeus.

1 Sönke Lorenz, Anton Schindling, and Wilfried Setzler eds., Primus Truber 1508-1586. Der slowenische Reformator und Württemberg (Tübingen, 2011). 
Habsburg Emperor Maximilian II (1564-1576) commissioned this north German reformer to compose the influential Kirchenordnungen for both Upper and Lower Austria. Then there is the tradition of Polish biblical literature. The Commonwealth's Protestant, Catholic, and Antritrinitarian communities produced a remarkable series of Polish translations of Scripture. ${ }^{2}$ The philological work of Lithuania's "most famous heretic" Szymon Budny is intriguing. Budny was the first scholar of this era to use material known both in the west and the east (Church Slavonic sources) in his humanist critique of Scripture. ${ }^{3}$ This chapter will proceed, however, with a more focused examination. We offer two case studies. We begin with the Czech lands and track the development of religious literature from the era of Charles IV into the 17th century. Then we turn to Hungary. Despite the disaster that overtook the kingdom with the Ottoman victory at Mohács in $15^{26}$, vernacular literature flourished in the 16th century as humanist impulses combined with newer confessional influences.

\section{Howard Louthan, The Czech lands}

Though this article will focus primarily on book production in the Czech lands during the 16th century, it is important to begin with a series of more general observations that help set the religious literature of this period in a broader chronological and thematic context. Most significantly, the religious developments of the 16th century were only a part of a longer era of reform. A fuller examination of "Bibles and books" in the Czech lands should properly begin in the middle of the 14th century with an assessment of Emperor Charles IV $\left(1355^{-1378)}\right.$. Charles is particularly important in terms of religion, for with him we see late medieval piety and spirituality with all its richness, complexity, and diversity reaching a high point in the Bohemian lands. Through his energy and enterprise he assembled one of the greatest collections of relics in all of Christendom. He founded Central Europe's first university, began work on one of the Continent's great Gothic cathedrals, and with the assistance of his allies persuaded the Pope to elevate Prague to an archbishopric. ${ }^{4}$ Not surprisingly, the first translations of biblical literature into Czech also date from this period. Charles initiated a trend that continued through the beginning of the $15^{\text {th }}$

2 Especially important here is the ambitious Biblia Slavica series.

3 David Frick, "Szymon Budny and Sacred Philology. Between East and West," Commentary to Biblia Slavica, Serie II: Polnische Biblen, Vol. 3, Part 2 (Paderborn, 1994), p. 344.

4 On Charles and religion see David Mengel, "Bones, Stones and Brothels: Religion and Topography in Prague under Emperor Charles IV (1346-78)" (Ph.D., University of Notre Dame, 2003). Barbara Drake Boehm and Jiří Fajt eds., Prague. The Crown of Bohemia 1347-1437, (New Haven, 2005). 
century. Bohemia became one of the key centres of European book production and would have arguably remained so had it not been for the disturbances of the Hussite period. ${ }^{5}$ When examining religious literature of the 16 th century, we must remember this long chronology, for groups such as the Unity of Brethren reflected influences ranging from the Devotio Moderna to John Calvin. ${ }^{6}$

In similar fashion we also need to take into account the religious diversity of the region. The Czech lands, as noted elsewhere in this volume, were one of Europe's earliest multi-confessional societies. With the 1485 Peace of Kutná Hora, Bohemia became Europe's first legally bi-confessional state by guaranteeing the rights of both Catholics and Utraquists. By this date, in fact, there were three well-established churches as the Unity of Brethren had also emerged as an independent religious community. With the coming of the Reformation the situation became even more complicated. Lutheran and later Calvinist influences shaped confessional discourse while persecuted groups of Anabaptists found refuge in Moravia. Not surprisingly, this diversity was reflected in print culture. In western Bohemia the town of Plzen developed a reputation as a bastion of Catholic printing. Shortly after the Jesuits arrived in the Czech lands (1556), they established a press at the Clementinum, their college in Prague. Utraquist literature was distributed widely throughout the period while the Brethren started their own printing centres including the one at Kralice where they produced the most important Czech translation of the Bible in the second half of the 16th century. Even the Anabaptists imported their own printers as they set up a shop in their southern Moravian refuge of Mikulov (Nikolsburg). ${ }^{7}$

Not surprisingly, with such religious diversity we also need to consider the multi-lingual nature of print culture in the Bohemian lands. Though the use of Czech as a literary language began to expand in the era of Charles IV, it had a longer pedigree. In the gth century Cyril and Methodius introduced a Slavonic liturgy. While the Pope interdicted these rites after the death of the missionary brothers, its practice survived in certain areas up through the 11th century, and the language continued to evolve in other genres. The oldest known song from the Bohemian lands, "Hospodin pomiluj ny" (Lord have mercy on us), dates from the end of the 1oth century. The early 14th-century Chronicle of

5 Uwe Neddermeyer, Von der Handschrift zum gedruckten Buch, 2 vols. (Wiesbaden, 1998), 2:657; Michael van Dussen, From England to Bohemia. Heresy and Communication in the Later Middle Ages (Cambridge, 2012).

6 Here see the extensive bibliography compiled by Jiří Just, http://www.etf.cuni.cz/kat-cd/ biblgr-jb-just.htm.

7 V. Tobolka, “Knihtiskař Simprecht Sorg-Froschauer," Časopis Matice moravské 53 (1929), $501-508$. 
Dalimil was the first written in Czech, and a century later the Hussites reclaimed the language for liturgical use. With the arrival of the printing press Czech reached new heights especially as the favoured language of the Utraquist community. Of the 44 surviving incunabula produced in Bohemia proper 39 are in Czech! ${ }^{8}$ Latin, however, experienced a minor renaissance of its own. Though humanism came late to the Bohemian lands, its spread cut across confessional divisions and helped reinvigorate use of the language in the region. Matthaeus Collinus, a former student of Philipp Melanchthon, became an influential figure at the University in Prague where he lectured on Virgil, Cicero, and Ovid. In Moravia a series of learned bishops including Stanislaus Thurzo and Johannes Dubravius, established a small humanist at the episcopal court. ${ }^{9}$

German was also a significant part of the region's literary culture. Indeed,

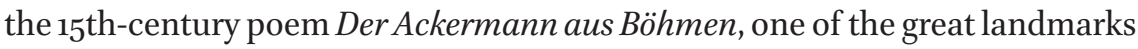
of Frühneuhochdeutsch, was written by a solicitor from western Bohemia, Johannes von Tepl. In the 16th century there were figures like Matthäus Aurogallus who as a youth fell under the spell of one of Bohemia's most important humanists, Bohuslav Hasištejnský of Lobkovic. Later in life, Aurogallus helped revise Luther's German translation of the Old Testament. German was particularly important in the north and west of Bohemia, a region where there was a substantial Lutheran influence. ${ }^{10}$ Finally, we should not forget Hebrew. Jewish printers in Prague produced the first Hebrew book in 1512. Their work was of high quality and included the beautifully illustrated $15^{26}$ Passover Haggadah. Later in the century, Hebrew printing expanded to Moravia while Prague itself also became a vibrant centre of Yiddish printing in the first half of the 17 th century. ${ }^{11}$

In what ways did Bohemia reflect the culture of the Renaissance through its books? Though figures such as Petrarch and Cola di Rienzo visited the Czech lands, the region's intellectual evolution was very different from that of Italy. The Hussite wars kept the kingdom isolated in the first half of the $15^{\text {th century, }}$

8 Mirjam Bohatcová, "The book and the Reformation in Bohemia and Moravia," in The Reformation and the Book, ed. Jean-François Gilmont, trans. Karin Maag (Aldershot, 1998), p. 389; in Moravia, in contrast, the majority of the incunabula were in Latin.

9 Martin Rothkegel, Der lateinische Briefwechsel des Olmützer Bischofs Stanislaus Thurzó. Eine ostmitteleuropäische Humanistenkorrespondenz der ersten Hälfte des 16. Jahrhunderts (Hamburg, 2007).

10 R. Wolkan, Böhmens Anteil an der deutschen Literatur des XVI. Jahrhunderts, 3 vols. (Prague, 1890-94).

11 Olga Sixtová ed., Hebrew Printing in Bohemia and Moravia (Prague, 2012). Lenka VeseláPrudková, Židé a česká společnost v zrcadle literatury: od středověku k počátkům emancipace (Prague, 2003). 
and religious tensions continued to stunt its cultural development. When Bohemia's new Jagiellonian kings attempted to introduce humanist disciplines at the university, they encountered stiff resistance. As opposed to Cracow where the new learning gained a foothold in the late 15th century, Prague's Utraquist masters, fearing the influence of potential Catholic rivals, jealously guarded the old medieval curriculum. In short, religion constituted a significant cultural filter through which humanist ideas passed. The well-traveled Aeneas Sylvius Piccolomini, future Pope Pius II, claimed that Bohemia's peasant women knew their Bible better than most Italian priests. ${ }^{12}$ Among the learned there was significant suspicion of Classical learning. Archbishop Jan Rokycana (c.1390-1471) warned of the pagan influence of Aristotle while the Brethren leader Jan Blahoslav (1523-1571) characterized Ovid as "an excellent master of Satan's work". When university students staged Plautus's Miles gloriosus in 1535, the main actor landed in prison for three days while Prague's conservative Utraquist authorities banned any further production of "pagan plays".13 Even those who were more favourably disposed to Greek and Roman literature frequently made use of this material for confessional purposes. Notable here is the humanist Řehoř Hrubý of Jelení whose rendering of Erasmus's The Praise of Folly in Czech (1513) was the first into a vernacular language. He was better known, though, for translating the work of Classical authors including Cicero. In his Warning to Prague Citizens, he made ample use of the Roman orator in his spirited defence of the Utraquist church. ${ }^{14}$

Printing came to Bohemia from the west, possibly from the Franconian town of Bamberg. The first shop was not in Prague but in Plzeň, and though an earlier generation claimed that the first book rolled off its presses in 1468, most scholars now date the advent of printing here to the mid-1470s. ${ }^{15}$ The industry quickly established itself across the region as there were a number of factors that contributed to its rapid growth and spread. Politically, the Peace of Kutná Hora eased confessional tensions. The Utraquist nobility enjoyed numerous privileges and freedoms while the weak Jagiellonian princes could not or would not impose significant restrictions on the new business. The increasing importance of Czech in both civic and religious life encouraged printing in the

12 M.E. Ducreux, "Reading unto death: books and readers in eighteenth-century Bohemia," in The Culture of Print, ed. Roger Chartier (Oxford, 1989), p. 219.

13 Josef Macek, "Bohemia and Moravia," in The Renaissance in National Context, eds. Roy Porter and Mikuláš Teich (Cambridge, 1992), pp. 202, 209.

14 Lexikon české literatury, vol. 2 (Prague, 1993), pp. 339-340.

15 Jiří Just, “Knižní kultura české reformace," in Umění české reformace (1380-1620), eds. Kateřina Horníčková and Michal Šroněk (Prague, 2010), pp. 335-354. 
vernacular. The growing ties of the Bohemian Brethren with both Lutheran and Reformed communities also stimulated demand for religious literature among the laity. Approximately 4,00o printed works survive from the 16 th century. More than half of them are in Czech. Nearly 1,500 titles are in Latin with the remainder in German, Hebrew, and a handful of other languages. Not surprisingly, Prague became the centre of this industry. More than forty printers worked in the city in the second half of the 16th century. Smaller clusters of printers emerged in Plzeň and Olomouc. There were also the shops outside the cities that frequently grew up around local religious communities. Across Bohemia and Moravia provincial towns such as Litomyšl, Mladá Boleslav, and Prostějov boasted presses of their own. ${ }^{16}$

In the middle of the 16th century the printing house of Jiří Melantrich of Aventinum emerged as the real pacesetter in Prague. ${ }^{17}$ Melantrich, who came from an Utraquist family of modest means, set up a shop that maintained very high standards. His beautifully produced editions of Mattioli's Herbarium (Czech 1562, German 1563) enjoyed immense success across Central Europe. His work eventually earned him a seat on the city council of Prague's Old Town. The humanist printer published across the religious spectrum. From the Lutheran catechism of Urbanus Rhegius to the fiery sermons of Girolamo Savonarola, from the satire of Erasmus to lavishly illustrated Catholic postils, Melantrich's workshop produced a broad array of religious literature. Most important was the so-called Melantrich Bible first published in 1549. This Czech translation of Scripture was one of the great landmarks of Bohemian literature and a testimony of a rich tradition of vernacular Bibles, one that predated the Reformations of the 16th century by nearly two hundred years.

Serious discussion of this tradition must begin with the Luxembourg princes. During the reign of John of Bohemia (1310-1346), a gifted team of scribes created one of the most remarkable illustrated manuscripts of late medieval Central Europe, the Velislav Bible. ${ }^{18}$ The Velislav Bible included nearly $75^{\circ}$ illustrations from the Old and New Testaments, scenes from saints' legends and a pictorial cycle of the Antichrist. Though the accompanying text was in Latin, vernacular Bibles would soon be produced with John's son and successor, Emperor Charles IV. We have reports from John Wyclif that Charles' daughter, Anne, received a Czech New Testament as a gift when she married

\footnotetext{
16 Bohatcová, “The book and the Reformation," pp. 390-391.

17 Jiří Pešek, Jiř́ Melantrich z Aventýna: př́běh pražského arcitiskaře, Slovo k historii 32 (1991).

18 Antonín Matějček, Velislavova bible a její místo ve vývoji knižní ilustrace gotické (Prague, 1926).
} 
England's Richard II. ${ }^{19}$ Though Czech glosses on Latin Bibles were produced earlier, the first translations of the Gospels date from the beginning of the 14th century. The oldest translation of the entire Bible was produced in the 1350 s most likely by a group of Benedictines and Dominicans for a cloister in Prague. Scribes made copies of this original Czech translation. The most important of these transcriptions was the so-called Dresden Bible. Though destroyed during World War, the text was photographed and is the oldest surviving Bible not only in Old Czech but in any Slavic language. This Old Czech translation went through three further redactions over the next century and a half. ${ }^{20}$

The last of these redactions occurred just as the new print medium was being established in Bohemia. Printers produced the first Psalter in 1487 while they released an entire Bible in Prague the following year. The most important of these incunabula appeared in 1489 in the prosperous mining town of the Kutná Hora. ${ }^{21}$ This richly decorated Bible included over one hundred woodcut illustrations. There was a strong element of civic pride and even competition in the production of these early Bibles. The Kutná Hora Bible was financed with a generous loan from the town. These same dynamics helped fuel the production of Czech Bibles in the following century. Three wealthy citizens of Old Town Prague helped underwrite the costs of the popular 1506 Venice Bible, the first Czech translation from a print shop outside the kingdom. Though there were a number of other Czech editions in the first half of the 16 th century, the most important of these was the aforementioned Melantrich Bible. It was of high quality both as a physical object and as an intellectual product, for the New Testament translators used not the Vulgate but the Greek. The Melantrich Bible included nearly 150 illustrations, some taken from Luther's 1535 German translation while others were created specifically for this project. The moderate Melantrich clearly hoped that his Bible's appeal would cross confessional lines. He did not misjudge his audience, for there were five editions in less than thirty years. ${ }^{22}$

All this activity had an impact far beyond Bohemia. Czech Bibles clearly influenced early Polish translations including the Cracow Psalter (1532) and

19 Alfred Thomas, Anne's Bohemia: Czech Literature and Society, 1310-1420 (Minneapolis, 1998), p. 44.

20 The best general overview of Czech Bibles is offered by Vladimír Kyas, Česká Bible v dějinách národního písemnictví (Prague, 1997); invaluable for reproductions of these early Slavic Bibles is the Biblia Slavica series.

21 R. Olesch and H. Rothe eds., Kuttenberger Bible. Kutnohorská Bible bei Martin von Tišnov, Biblia Slavica, Series 1 (Paderborn, 1989).

22 Pešek, Jiř́ Melantrich z Aventýna, pp. 6-9. 
the Leopolita Bible (1561). Prague itself became an important publishing centre for the region. The humanist Francysk Skaryna published the first Belarusian translation of Scripture in the city (1517-19), while the oldest Sorbian edition of the Bible was produced here in $1547 .{ }^{23}$ Critical developments were also occurring outside Prague. By the second half of the 16th century the Bohemian Brethren had established thriving publishing centres in the more tolerant Moravian lands and were busy working on their translations of Scripture. ${ }^{24}$ Using Theodore Beza's Greek/ Latin New Testament as a model, Jan Blahoslav produced a Czech New Testament in 1564. An even more ambitious undertaking began several years later in the village of Kralice. There the Brethren established a workshop and a specialized library with philological aids in Greek, Hebrew, Aramaic, and Latin. A team of scholars working from the original languages published a translation of the entire Bible in six volumes between 1579 and 1594 complete with scholarly commentary and marginalia. Single volume editions appeared in 1596 and 1613. With its archaizing language the 1613 Kralice Bible, the first that completely relied on the original languages, is still the best-known Czech translation of Scripture today. ${ }^{25}$

Though these Bibles were undoubtedly the highpoint of Czech literary culture of this period, there were other forms of religious literature that were distinctive of the region. There was a growing appetite for theological and devotional texts. The Brethren are particularly important in this regard. In the 16th century there was renewed interest in Petr Chelčický (died c.146o). A proponent of non-violence and a strong advocate of the separation of church and state, Chelčický was in many respects the spiritual founder of the Unitas Fratrum. In the 1520 s printers published both a collection of his sermons as well his great masterpiece, The Net of Faith, Chelčickýs radical critique of Christendom that later had such an impact on Leo Tolstoy. ${ }^{26}$ On the other hand, printers generally avoided Hus. Those who published his works were

23 Františka Sokolová, Francisko Skoryna v díle českých slavistů: sborník k 5oo. výročí narození významného běloruského humanisty 1490-199o (Prague, 1992). A.V. Florovskij, "Češskaja biblija v istorii russkoj kul'tory i pis'mennosti,” Sborník filologický 13 (1940-46), 135-258. Vladimír Kyas, “Česká předloha nejstarší lužickosrbské jazykové památky," Slavia 33 (1964), 369-374.

24 Mirjam Daňková, Bratrské tisky Ivančické a Kralické (Prague, 1951).

25 H. Rothe ed., Kralitzer Bible. Kralická Bible, Biblia Slavica, Series 1, 6 vols. (Paderborn, 1995).

26 For this edition of the Net of Faith see Z. Tobolka ed., Knihopis českých a slovenských tiskü od doby nejstarši až do konce 18. století (Prague, 1925-67), \#3303. On Chelčický see Jaroslav Boubín, Petr Chelčický. Myslitel a reformátor (Prague, 2005); in English see F. Murray L. Wagner Petr Chelčický. A Radical Separatist in Hussite Bohemia (Scottdale, PA, 1983). 
most frequently based in provincial outposts such as Mladá Boleslav, Litomyšl, or outside Bohemia altogether. The first print edition of Hus's well-known Czech Postil appeared not in Prague but in Nuremberg in 1563.

The most prolific of the Czech reformers was Luke of Prague (146o?-1528). One of the most fascinating figures of the Bohemian Reformation, Luke traveled extensively throughout the Mediterranean seeking Christian communities following an "apostolic" model. In Florence he witnessed the execution of Savonarola and in Constantinople dialogued with the Orthodox. He later corresponded with Luther. Luke's Dětinské otázky (Children's Questions) (1501/o2) is considered the oldest Protestant catechism. It is important to remember that unlike the Utraquists and Catholics, the Unity was not granted freedom of worship. In part as a way to defend themselves, the Brethren issued nearly twenty confessional statements from the late $15^{\text {th }}$ to the 17 th centuries. ${ }^{27}$ Luke was a critical part of this process of self-definition. During his long career he wrote over one hundred theological works eagerly published by the Brethren's printers. ${ }^{28}$ There was also growing interest in religious developments outside the Czech lands. Bohemians translated not only major figures such as Luther and Calvin but also took on the texts of Johannes Bugenhagen, Heinrich Bullinger, and Martin Bucer. Catholics, too, had their favorites including Stanislas Hosius, the Polish cardinal who was emerging as one of Rome's most important apologists. ${ }^{29}$

Apart from Bibles the most distinctive feature of Czech religious literature was the wide production of the hymnal or kancionál. Bohemia's rich musical tradition in many respects began with the missionary brothers Cyril and Methodius who introduced liturgical chant. Though Rome proscribed Old Church Slavonic in the 11th century, singing did continue. We have datable Czech songs from the 14th century and in the 15th musical notation for melodies such the "St Wenceslas" chorus, which would later be used by composers such as Antonín Dvořák and Josef Suk. The Hussites were famous for their martial anthems including "Ktožjsú Boží bojovníci" (Those who are God's warriors), which they purportedly sang as they marched into battle. Hus himself recommended the use of vernacular songs and hymns in the Mass, a practice that was particularly popular with the Advent Rorate chant. Congregational singing

27 Milos Strupl, "Confessional Theology of the Unitas Fratrum," Church History 33 (1964), 279-293.

28 Amedeo Molnár, Bratr Lukáš. Bohoslovec Jednoty (Prague, 1948). C. Daniel Crews, "Luke of Prague: Theologian of the Unity," The Hinge 12 (2005), 21-54. Craig D. Atwood, "Catechism of the Bohemian Brethren," Journal of Moravian History 2 (2007), 91-117.

29 Tobolka, Knihopis českých a slovenských tisků, \#1363, 1367, 1386, 1406-08, 3195, 5061-5128. 
became a key feature of Hussite worship. Though both Catholics and Utraquists eventually compiled their own songbooks including the well-known Jistebnický kancionál from the early 15th century, it was the Brethren who most fully appropriated this musical legacy. Their first kancionál appeared in 1505. Others quickly followed, and versions were translated in German and Polish. The genre reached a highpoint with their bishop, Jan Blahoslav (1523-1571). Blahoslav, who had studied at Basel and Wittenberg, was a gifted scholar and musician. He published a monograph on music theory and served as the chief editor of an especially successful hymnal. So popular were Brethren songbooks that the Jesuit Václav Šturm bitterly complained that a 1576 edition was virtually ubiquitous. "Everyone, nobles and peasants, rich and poor, have this book at home". 30

Most scholars see this literary era coming to a close with the defeat of the Bohemian estates at the 1620 Battle of White Mountain. The kingdom lost many of its political rights and privileges. The Habsburgs became hereditary monarchs. Protestants either converted or left in exile, and a revivified Catholic culture dominated public life. Though certainly White Mountain signaled a significant sea-change, important aspects of the region's literary culture did survive albeit in modified form. Czech did not disappear as a literary language. It remained alive both at home through the efforts of Catholic preachers and devotional writers and also abroad in the work of the émigrés. In exile Jan Amos Komenský (also known as John Comenius) compiled the final songbook of the Brethren, but even in Bohemia the efforts of Protestant hymn writers were not forgotten. When Jan Josef Božan assembled a massive Catholic kancionál in the early 18th century, more than twenty per cent of the songs he included were of Protestant origin. The title page of Adam Michna of Otradovice's Music for the Liturgical Year (1661) was taken directly from the well-known Brethren hymnal of Jan Roh, complete with the figure of Jan Hus leading the congregation in song! ${ }^{31}$ Arguably the most important evidence of continuity was the last great Czech Bible of the early modern period. Building on the work of the Kralice Bible and other vernacular editions, the translators of the St Wenceslas Bible $(1677,1712$, and 1715$)$ created a new version that looked as much to the past as it pointed to the future. ${ }^{32}$

$30 \quad$ Cited in Bohatcová, "The book and the Reformation," p. 401.

31 Howard Louthan, Converting Bohemia. Force and Persuasion in the Catholic Reformation (Cambridge, 2009), pp. 241-242.

32 H. Rothe and F. Scholz eds., Svatováclavská bible, Biblia Slavica, Series 1, 2 vols. (Paderborn, 2001). 


\section{Pál Ács, 'Vernacular literature in Hungary'}

The beginning of the 16th century was marked by profound changes in Hungary's political, social, and cultural history. The medieval kingdom of Hungary collapsed in the face of the advance of Ottoman armies. The Catholic church lost lands, power, and the support of most of the population. ${ }^{33}$ Writing about this era of reform in Hungary has long been trapped in traditional contexts, and analysis of the history of religion in Hungary has only gradually lost an apologetic and confessional character. Debate has now moved to study of the origins, character, and development of reform movements, the role of religious orders, landowners, and laity in supporting reform, the reception of reform among different ethnic and social groups, and the impact of reform on social relations. ${ }^{34}$ In all these areas of analysis, a strange paradox must be addressed; that the political and cultural calamity for Hungary marked by the $15^{26}$ battle of Mohács was followed by the spectacular development of Hungarian vernacular literature. ${ }^{35}$ We should acknowledge that there had been traditions of vernacular literature before the 16th century, although largely confined within religious contexts. ${ }^{36}$ The spread of vernacular printed texts was in part a result of the reception of humanism and influence of Erasmus in Hungary. However, the accent placed on the vernacular within various programmes of religious reform was certainly closely connected with the growth of literary communication in Hungary and the increasing role of Hungarian in printed literature. We know in some detail that there was a rapid expansion in the production of printed vernacular works in Hungary. The bibliography of

33 Ferenc Szakály, "Nándorfehérvár, 1521: The Beginning of the End of the Medieval Hungarian Kingdom," in Hungarian-Ottoman Military and Diplomatic Relations in the Age of Süleyman the Magnificent, eds. Géza Dávid, Pál Fodor (Budapest, 1994), pp. 47-76. Géza Pálffy, The Kingdom of Hungary and the Habsburg Monarchy in the Sixteenth Century (New York, 2009).

34 Katalin Péter, A reformáció: kényszer vagy választás? (Budapest, 2004). Zoltán Csepregi, "Die Auffassung der Reformation bei Honterus und seinen Zeitgenossen," in Humanistische Beziehungen in Ungarn und Siebenbürgen: Politik, Religion und Kunst im 16. Jahrhundert, eds. Ulrich A. Wien and Krista Zach (Vienna, 2004), pp. 1-17.

35 Zoltán Ferenczi, "La lingua volgare nella letteratura ungherese," Corvina 1 (1921), 53-58. Pál Ács, "A magyar irodalmi nyelv két elmélete: az erazmista és a Balassi-követő," Irodalomtörténeti Közlemények 86 (1982), 391-403. Mike Pincombe, "Evolutionary Experiment in the Lyric Poetry of Bálint Balassi," Journal of Northern Renaissance 3 (2011).

36 János Horváth, A magyar irodalmi müveltség kezdetei. Szent Istvántól Mohácsig (Budapest, 1931). Andor Tarnai, “A magyar nyelvet írni kezdik”. Irodalmi gondolkodás a középkori Magyarországon (Budapest, 1984). Edit Madas, "Írás, könyv és könyvhasználat a középkori Magyarországon, 1000-1526," in A könyvkultúra Magyarországon a kezdetektôl 1730-ig, eds. Edit Madas and István Monok (Budapest, 1998), pp. 11-16. 
16th-century Hungarian printed works consists of some 869 items, while the repertory of 16 th-century verse extends to 1,500 poems. ${ }^{37}$ Use of the Hungarian language spread rapidly during this period not only in print, politics, and public life but also in private correspondence and personal exchanges. ${ }^{38}$

Latin had long dominated religious life, scholarship, and literature in Hungary. The transition towards increasing use of Hungarian was far from seamless. Authors in Hungary, as elsewhere across the Continent, wondered whether their vernacular language was in fact capable of offering accurate and appropriate forms of the sacred languages used in the Bible. ${ }^{39}$ János Sylvester (c.1504-c.1551), a follower of Erasmus, perceived a struggle between languages ("glottomachia") to discern which was best suited for the task of translating early Church or Classical texts or for creating new works of the same quality as those of ancient writers. ${ }^{40}$ The degree of influence of Erasmus over Sylvester and others in Hungary can hardly be under-estimated. ${ }^{41}$ Hungarians had studied Erasmus's texts before the battle of Mohács. A second group of Erasmians then emerged after Mohács with an agenda to spread knowledge of the Bible

37 Madas, A könyvkultúra Magyarországon 1730-ig. Gedeon Borsa, "Le livre et les débuts de la Réforme en Hongrie," in La Réforme et le livre. L'Europe de l'imprimé: 1517- v. 1570, ed. J.F. Gilmont (Paris, 1990), pp. 375-392. Judit V. Ecsedy, A könyvnyomtatás Magyarországon a kézisajtó korában: 1473-180o (Budapest, 1999). Régi Magyarországi Nyomtatványok I-IV (Budapest, 1971-2012). Répertoire de la poésie hongroise ancienne, 2 vols., ed. Iván Horváth (Paris, 1992). Régi Magyar Költők Tára 12 vols. (Budapest, 1877-2004).

38 Sándor Takáts, "Batthyány Ferencné Bánffy Kata," in Régi magyar asszonyok (Budapest, 1914), pp. 30-58.

39 Angelo Mazzocco, Linguistic Theories in Dante and the Humanists. Studies of Language and Intellectual History in Late Medieval and Early Renaissance Italy (Leiden, 1993), pp. 30-50. Pieter Adrianus Verburg, Language and its Functions. A Historico-Critical Study of Views Concerning the Functions of Language from the Pre-Humanistic Philology of Orleans to the Rationalistic Philology of Bopp (Amsterdam, 1998), pp. 123-191. Guy Bedouelle, "Érasme, Lefèvre d'Étaples et la lecture de la Bible en langue vulgaire," in Lay Bibles in Europe 1450-180o, eds. Mathijs Lamberigts and A.A. Den Hollander (Leuven, 2006), pp. 55-68.

40 Ioannes Sylvester, Grammatica Hungarolatina (Sárvár-Újsziget, 1539), ed. István Bartók (Budapest, 2006), p. 115 .

41 Imre Trencsényi-Waldapfel, Erasmus és magyar barátai (Budapest, 1941). Ágnes RitoókSzalay, "Erasmus und die ungarischen Intellektuellen des 16. Jahrhunderts," in Erasmus und Europa, ed. August Buck (Wiesbaden, 1988), pp. 111-128. Pál Ács, "Hungarian Friends of Erasmus in the Sixteenth Century and Today," in In Search of the Republic of Letters. Intellectual Relations between Hungary and The Netherlands 1500-1800, ed. Arnoud Visser (Wassenaar, 1999), pp. 21-28. 
and to translate the Scripture into the vernacular. The first printed book in Hungarian was published at Cracow, and was appropriately a translation of the Epistles of Paul, following Erasmus's work. ${ }^{42}$

As we turn to consider the significance of this Erasmian legacy and of programmes of religious reform on the production of vernacular texts, we should consider the changing landscape of Hungarian scholarship in this field. From the 19th century onward literary historians in Hungary suggested that early reformers sought to undermine Catholicism by turning directly to the people and speaking to them in their own language. This conviction nurtured the notion that the age of Matthias Corvinus and of the Jagiellonian kings was an era of Renaissance in Hungarian literature. This was followed by one hundred years of Reformation, which in turn was succeeded by the long reign of the Counter-Reformation Baroque. ${ }^{43}$ Some authors have offered a damning verdict about the long-term cultural impact of the Reformation. ${ }^{44}$ This traditional pattern of Hungarian literary history was only finally replaced during the second half of the 2oth century. Scholars then brought together and united what they identified as the progressive movements of the Renaissance and Reformation creating an extended Renaissance period of Hungarian literature that reached into the third decade of the $17^{\text {th }}$ century. According to this scheme, religious literature and secular literature were two branches of the same organic development and were both nourished from ancient sources and from clean wells of faith and culture. Vernacular secular culture and Protestant literature in Hungary were thus seen to stem from the same roots. ${ }^{45}$

This view has been rightly disputed by those who point out that the enthusiasm of reformers for the vernacular was primarily a means to an end, and

42 Benedek Komjáti, Epistolae Pauli lingva hungarica donatae. Az Zenth Paal leueley magyar nyeluen (Cracow, 1533), and ed. Áron Szilády (Budapest, 1883). Pál Ács, “The Reception of Erasmianism in Hungary and the Contexts of the Erasmian Program: The 'Cultural Patriotism' of Benedek Komjáti', in’Whose Love of Which Country?' Composite States, National Histories and Patriotic Discourses in Early Modern East Central Europe, eds. Balázs Trencsényi and Márton Zászkaliczky, (Leiden, 2010), pp. 75-90.

43 László Szörényi, "Introduzione alla recente storiografia sul Rinascimento in Ungheria," in Italy and Hungary. Humanism and Art in Early Renaissance. Acts of an International Conference Florence, Villa I Tatti, 6-8June, 2007, eds. Péter Farbaky and Louis A. Waldman (Florence, 2011), pp. 45-54. János Horváth, A reformáció jegyében (Budapest, 1957).

44 Friedrich Nietzsche, Human, All Too Human. A Book for Free Spirits, transl. Marion Faber, Stephen Lehmann (Lincoln, NE, 1997), p. 147.

45 Tibor Klaniczay, "Hungary," in The Renaissance in National Context, eds. Roy Porter and Mikuláš Teich (Cambridge, 1992), pp. 163-180. 
that Protestants did not use Hungarian in print with literary motives in mind. ${ }^{46}$ Indeed some reform-minded preachers attacked "lecherous" secular poetry and directed prophetic diatribes against expressions of Renaissance culture. In their eyes, dancing, music, and the recital of love songs were all forms of "ugliness" that stemmed from the devil. Reformers condemned comedy as an obscene vanity, and likewise denounced colourful forms of dress and decorative styles of architecture. ${ }^{47}$ Péter Bornemisza was an evangelical author responsible for the first printed work of fiction in Hungarian. In his version of Sophocles' Electra, Bornemisza offered a moral judgement through his characters with a clear contemporary resonance. Bornemisza's murderous and lustful Clytemnestra was a typical Renaissance woman who sought only pleasure from life; "she has music played for her ..., she feasts ..., she dances, has fun". Bornemisza also condemned Clytemnestra's "rascal" of a partner, Aegisthus in similar terms. Bornemisza's Aegisthus described how his "utmost aim is to have numerous lute-players, violinists, pipers, drummers, trumpet-players, to see everyone have fun, to have young people around me enjoying themselves, to see beautiful people dance ... and wrap palaces in golden, expensive upholstery and golden velvet". ${ }^{48}$ Other reformers retained this strong suspicion of Classical pre-Christian forms of ancient culture. Imre Újfalvi, who compiled a 1602 hymn book at Debrecen, wondered "how [Christ] could love those who sing not to him but to Jupiter, Venus, Bacchus, or Vulcan, all those who were wrongly considered gods by the pagans". ${ }^{49}$

Traditional literary scholars in Hungary were aware of the tensions identified by some authors between the values of the Renaissance and the Reformation. Literary historians responded by narrowing the concept of vernacular

46 Iván Horváth, “A magyar vers a reneszánsz és a reformáció kezdetén," in A magyar irodalom történetei. A kezdetektől 180o-ig, eds. László Jankovits, Géza Orlovszky (Budapest, 2007), pp. 351-362. Bengt Hägglund, "Erasmus und die Reformation," in Erasmus und Europa, ed. August Buck (Wiesbaden, 1988), pp. 139-148.

47 Pál Ács, “Thou Shalt Not Commit Adultery'/ 'Ne paráználkodjál'. The Metaphor of Adultery/ Paráznaság as applied in the Literature of the Reformation," in Der Mythos von Amor und Psyche in der Europäischen Renaissance, eds. József Jankovics and S. Katalin Németh (Budapest, 2002), pp. 11-18.

48 Péter Bornemisza, Tragédia magyar nyelven az Szophoklész Élektrájából (Vienna, 1558), and eds. Péter Kőszeghy, Szabolcs Oláh (Budapest, 2009), pp. Avi v, Biii r.

49 Imre Újfalvi, Keresztyéni énekek (Debrecen, 1602), and eds. Péter Kőszeghy and Pál Ács (Budapest, 2004), pp. 1 a. Bálint Keserű, "Der Fall Imre Újfalv Di reformierte Opposition in Ostungarn und die Melanchthon-Anhänger in Sachsen," in Deutschland und Ungarn in ihren Bildungs- und Wissenschaftsbeziehungen während der Renaissance, eds. Wilhelm Kühlmann and Anton Schindling (Stuttgart, 2004), pp. 185-197. 
Renaissance to artistic and courtly literature. Only works by the most brilliant Renaissance poets such as Bálint Balassi (educated by Péter Bornemisza) and János Rimay were seen to fulfill the strict criteria required of Renaissance literature. ${ }^{50}$ Meanwhile, most 16 th-century century Hungarian texts were simply not considered as Renaissance literature because such books were deemed to have been written "in the spirit of the Reformation". ${ }^{51}$ Contemporaries had a very different view. János Rimay was a deeply pious evangelical who wrote a preface to the collected love poems of Bálint Balassi. Rimay collected and wanted to print the complete works of Balassi, but this edition was never published, and only Rimay's preface has survived. Rimay defended Balassi's love poetry as aiding the development of Hungarian as a literary language. Rimay also argued that Balassi's love poems were as well suited as any other poetry to voice wisdom. Rimay's preface set these remarks in the context of a broader assessment of Hungarian literary and religious history. Rimay noted that the sciences, "manual crafts", and arts had developed so that they could finally compete with "works of old times". A similar step had also been taken in the "writing professions". Finally, "God has given us a beautiful gift, having enriched this era with the perfect manifestation of His Word, the true knowledge of His Holy Son, and the unambiguous revelation of His will". For Rimay, the achievements of Hungarian humanism pointed directly towards the Reformation. True faith was the light of a "heavenly torch" that had chased away ignorance. The Latin language had been restored to its true nature and "all national languages" had started to speak for themselves. According to Rimay, the final result and glorious perfection of this renovation and reform, carried out in accordance with God's will, was exemplified in Bálint Balassi's love poetry. ${ }^{52}$ In Rimay's eyes, humanism, the Renaissance, the Reformation, and the development of Latin and vernacular languages, were all part of a single, unstoppable process. This process for Rimay, as for all Protestants, was not progressive in the sense of denying the past but rather the recovery of a lost golden age. ${ }^{53}$

$50 \quad$ Armando Nuzzo, "Il Balassa-kódex e le raccolte poetiche di Bálint Balassi e János Rimay," in "Liber", "fragmenta", "libellus" prima e dopo Petrarca. In ricordo di D'Arco Silvio Avalle, eds. Francesco Lo Monaco, Luca Carlo Rossi and Nicola Scaffai (Florence, 2006), pp. 325348. Pincombe, "Evolutionary Experiment in the Lyric Poetry of Bálint Balassi".

51 Horváth, A reformáció jegyében.

52 János Rimay, Összes müvei, ed. Sándor Eckhardt (Budapest, 1955), pp. 39-40.

53 Konrad Burdach, "Sinn und Ursprung der Worte Renaissance und Reformation," Sitzungsberichte der preußischen Akademie der Wissenschaften. Phil.-hist. Klasse 32 (1910), 594-646. Anthony Levi, Renaissance and Reformation: The Intellectual Genesis (New Haven, 2002). 
Across the 16th century the volume of printed vernacular texts steadily increased over a range of different genres, forms, and subject matter. While the aesthetic quality of some work falls short of the standard set by the Balassi school, they still retain serious literary intent and significance. Protestant writers, some well known and others anonymous, composed many pedagogic and reproving poems, as well as histories, Biblical chronicles, and also folkloric and sometimes humorous odes to newly-married couples. Noteworthy early authors of vernacular texts influenced by the Reformation include Sebestyén Tinódi who composed histories in verse. ${ }^{54}$ András Farkas, András Szkhárosi Horvát, and András Batizi were among preacher-poets who often incorporated Biblical parables to write about the imminent end of the world, the papal and Turkish Antichrists, and the moral corruption of Catholic priests, oligarchs, and princes. Adopting the voice of Old Testament prophets, they condemned public sins and the false worship of those who adhered to the religion of the Pope. ${ }^{55}$ All these preachers were convinced that the defeat of Hungary at the hands of the Ottomans provided a clear sign of God's punishment. A 1538 poem by Farkas explored his understanding of the parallel fate of the Hungarians and ancient Israel: "All this was inflicted upon us by God / Because of our many sins and wickedness. / He punished us by the pagan Turks, / And by the Germans and their many allies."56

Translations of the Psalms also flourished. Prose Psalms by Márton Kálmáncsehi and István Székely were followed by paraphrases in free verse by preachers including András Batizi, Mihály Sztárai, Gergely Szegedi, and Miklós Bogáti Fazakas. This style gave way to more precise and faithful renditions of the Psalms by Máté Skaricza, Albert Szenci Molnár, and János Thordai. ${ }^{57}$ Alongside these developing styles and uses of vernacular Psalms, hymns and songs were printed in various hymnals and graduals for use in public worship. ${ }^{58}$ A number of domestic printing houses produced these texts for use in Protestant churches including presses in the towns of Cluj (Kolozsvár), Oradea (Nagyvárad), Debrecen and Bardejov (Bártfa). The texts of these hymnals were

54 Sebestyén Tinódi, Cronica (Kolozsvár, 1554), and eds. István Sugár and Ferenc Szakály (Budapest, 1984). Balázs Pap, “Tinódi „bibliai históriái,” in Tinódi Sebestyén és a régi magyar verses epika, ed. Rumen István Csörsz (Cluj, 2008), pp. 87-98.

55 Tibor Klaniczay, "A magyar reformáció irodalma," in Reneszánsz és barokk (Budapest, 1961), pp. 64-150.

56 Balázs Pap, "Ment őket az Isten Egyiptomból kihozá," Acta Historiae Litterarum Hungaricarum 29 (2006), 211-219.

57 A zsoltár a régi magyar irodalomban, eds. Éva Petrőczi and András Szabó (Budapest, 2011).

$5^{8}$ Tibor Schulek, "Kurzer Abriß der Geschichte des ungarischen Kirchengesangbuches," Jahrbuch für Liturgik und Hymnologie 14 (1969), 130-140. 
sometimes copied manually by anonymous artisans into richly illustrated manuscript copies. ${ }^{59}$ Works of polemical drama also flourished. ${ }^{60}$ The most famous dramatist of the period was the versatile Mihály Sztárai (Mihajlo Starin). Vernacular print also included dogmatic tracts, polemic works, and collections of sermons including a volume compiled by Péter Bornemisza.

The Bible was first translated partially and then in its entirety. Some books of the Bible had been translated by Benedek Komjáti, Gábor Pesti, and János Sylvester. These versions were based on Erasmus's Novum Testamentum and were not used by later Protestant scholars. While later translators did continue to use the texts of the Septuagint and Vulgate, they relied increasingly on original Hebrew and Greek sources, available Polyglot Bibles, and new translations by Immanuel Tremellius and Peter Martyr Vermigli. ${ }^{61}$ The quality of this pioneering work steadily improved across the century with texts produced by Gáspár Heltai, Péter Melius, and Tamás Félegyházi. ${ }^{62}$ The most significant and complete 16th-century translation of the Bible was printed in 1590 at Vizsoly under the direction of Gáspár Károlyi. Later editions of the Bible by Albert Szenci Molnár and Miklós Tótfalusi Kis adapted this Vizsoly text, and the Bible was then translated afresh in its entirety by the Hebraist, György Komáromi Csipkés. ${ }^{63}$

The question arises about how to analyse this rather considerable corpus of early vernacular literature. These works are undoubtedly significant literary and cultural achievements in their own right but in what sense, if at all, can they be classified as Protestant? Did Hungary have a unified Protestant culture or did the Lutheran, Reformed, and Antitrinitarian churches each develop their own identifiable genres of literature? Hungarian intellectuals were of

59 Béla Stoll, A magyar kéziratos énekeskönyvek és versgyüjtemények bibliográfiája: 1542-1840 (Budapest, 2002).

60 Mihály Balázs, "Der 'Reformationsdialog' und die ungarischen Antitrinitarier," in Festschrift für András Vizkelety zum 7o. Geburstag, eds. Márta Nagy et al. (Piliscsaba, 2001), pp. 261-270. Miklós Latzkovits, A drámaírás gyakorlata a 16-17. századi Magyarországon (Budapest, 2007).

61 Mihály Imre, A Vizsolyi Biblia egyik forrása: Petrus Martyr (Debrecen, 2006).

62 István Nemeskürty, Magyar bibliafordítások Hunyadi János korától Pázmány Péter századáig (Budapest, 1990). Katalin Péter, "Bibellesen: Ein Programm für jedermann im Ungarn des 16. Jahrhunderts," in Iter Germanicum. Deutschland und die Reformierte Kirche in Ungarn des 16-17. Jahrhundert, ed. András Szabó (Budapest, 1999), pp. 7-38. Biblia Sacra Hungarica, eds. János Heltai and Botond Gáborjáni Szabó (Budapest, 2008).

63 András Szabó, Károlyi Gáspár (Budapest, 1982). Judit P. Vásárhelyi, Szenci Molnár Albert és a Vizsolyi Biblia új kiadásai: elözmények és fogadtatás (Budapest, 2006). György Haiman, Nicholas Kis. A Hungarian Punch-Cutter and Printer (1650-1702) (San Francisco, 1983). 
course very familiar with the debates and divisions between Lutheran and Reformed theologians in the Empire. ${ }^{64}$ Nevertheless, we should note that the process of developing distinct Reformed and Lutheran church institutions was relatively slow in Hungary, and the different branches of the reform movement did not irrevocably separate until the final decades of the 16 th century. ${ }^{65}$

In addition, we should note that some key authors changed their religious allegiances during this period. The spirituality of István Szegedi Kis had first been formed by the Observant Franciscans of Szeged, but he then supported Lutheran and later Reformed doctrine. Márton Kálmáncsehi Sánta, later known as an iconoclast, began his career as a canon of the cathedral at Alba Iulia (Gyulafehérvár). Ferenc Dávid was originally a Catholic priest. In 1557 he became superintendent of the Lutheran church in Transylvania, and then in 1559 he moved to a Reformed position, before in 1566 embracing Antitrinitarianism and then in 1570 adopting a non-adorantist form of Antitrinitarianism. Moving in the other direction Bálint Balassi became a Catholic in 1585 . The affiliation of some figures remains uncertain. Mátyás Dévai was nicknamed the "Hungarian Luther" by some contemporaries, but was considered to have moved in a "Swiss direction" by some, while others saw Dévai as an Anabaptist because of his views on the state of the soul after death. ${ }^{66}$ There were also difficulties and divisions within churches. For example, in the town of Kežmarok (Késmárk), there were lengthy debates between orthodox Lutheran and crypto-Calvinist clergy (Gergely Horváth Stansith and Sebestyén Ambrosius respectively). ${ }^{67}$ There were also tensions within churches over the authority of superintendents. A Reformed superintendent, Lukács Hodászi, called for the execution of Imre Újfalvi (who had compiled a 1602 hymnal) because he had rebelled against Hodászi's authority. ${ }^{68}$

In what ways did these varied religious trajectories and changing opinions affect the literature of the period? There were certainly no distinct literary or

64 Peregrinatio Hungarica: Studenten Aus Ungarn an deutschen und österreichischen Hochschulen vom 16. bis zum 20. Jahrhundert, eds. Márta Fata, Gyula Kurucz, and Anton Schindling (Tübingen, 2006).

65 Katalin Péter, "Hungary," in The Reformation in National Context, ed. Robert Scribner, Roy Porter, Mikuláš Teich (Cambridge, 1994), pp. 155-167.

66 Mátyás Dévai created the first systematic Hungarian system of spelling; see Orthographia hungarica (Cracow, 1538). Zoltán Csepregi, “A magyarországi reformáció kezdetei: Dévai Mátyá @agyar Luther," História 39 (2009), 26-31.

67 Marcen seoők, "Sebastian Thököly and his Sensibility Towards Religious Questions," in The Man of Many Devices, who Wandered Full Many Ways. Festschrift in Honour of János M. Bak, eds. Balázs Nagy and Marcell Sebők (Budapest, 1999), pp. 583-595. 
poetic styles or particular use of rhetoric and language that can be connected with any one confession. ${ }^{69}$ For example, concerning the vernacular Bible, the Vizsoly Bible and early 17 th-century translations emerged from a Reformed context, but Lutheran and Antitrinitarian churches used the same translations. The Lutheran church in Hungary did not complete its own Bible translation until the 18 th century. ${ }^{70}$ The most obvious differences between Protestant texts arise from questions of content but even here we can observe authors adopting different strategies that reflected the complex confessional environment. Hymnals for example included catechism verses, some of which closely reflected a distinct theological position on key issues while others were rather cautious in their treatment of contentious issues. When it came to treatment of the difficult question of Holy Communion in hymnals, one of the most divisive songs, "You are taking Christ's Communion", had two completely different texts one used by Lutherans and the other by Calvinists. Towards the end of the 16 th century, hymnals tended to avoid inclusion of contentious texts altogether. Imre Újfalvi's 1602 hymnal adopted a different strategy. He printed the Reformed text for "You are taking Christ's Communion" but next to it he placed a song on the Holy Communion that had previously only been printed in Lutheran collections of hymns. The theology of the two texts was obviously contradictory. The first emphasized that Christ's human body was in heaven, while the other stressed Christ's ubiquitous omnipresence. ${ }^{71}$

By the early decades of the 17 th century the growing force of confessionalism proved unstoppable. The development of separate Lutheran, Reformed, and Catholic religious cultures was reflected in new and distinct forms of vernacular literature. For example, Reformed students returned from periods of study at Dutch universities and visits to England with a commitment to spread a Puritan style of piety in Hungary. Pál Medgyesi and János Tolnai Dali were among those who returned home having experienced the use of vernacular books as instruments of personal moral reflection and practical divinity in Dutch and English congregations. Hungarian Puritan authors translated morality tracts, conduct books, and other works of practical theology aiming to transplant the same Puritan culture to Hungarian Reformed congregations. ${ }^{72}$ At the

69 István Bartók, "Rhetoricati sumus. Retorikafelfogások a régi magyar irodalomban," in Religió, retorika, nemzettudat a régi magyar irodalomban, ed. István Bitskey, (Debrecen, 2004), pp. 198-211.

70 Zoltán Csepregi, "Evangélikus bibliafordítások a 18. században," in Biblia Hungarica Philologica, ed. János Heltai (Budapest, 2009), pp. 171-184.

71 Újfalvi, Keresztyéni énekek, pp. 35-38.

72 Graeme Murdock, Calvinism on the Frontier, 1600-1660: International Calvinism and the Reformed Church in Hungary and Transylvania (Oxford, 2000). 
same time some voices continued to be raised in print in favour of religious peace and irenicism. Imre Újfalvi encouraged dialogue between churches, while János Rimay urged that "we must be patient towards differences between religions". In the end, however, these sentiments in favour of Christian unity, while in line with the original aims of Hungarian reformers, were unable to withstand the growing confessional pressures of the $17^{\text {th }}$ century. ${ }^{73}$

\section{Select Bibliography}

\section{Bohemia}

Atwood, Craig, The Theology of the Czech Brethren from Hus to Comenius (State College, PA, 2009).

Bohatcová, Mirjam, "The book and the Reformation in Bohemia and Moravia," in The Reformation and the Book, ed. Jean-François Gilmont, trans. Karin Maag (Aldershot, 1998), pp. 385-409.

Bohatcová, Mirjam, ed., Česká kniha v proměnách staletí (Prague, 1990).

Bohatcová, Mirjam, Die Gesangbücher der Brüderunität und ihre graphische Gestaltung

(Prague, 1989).

Daňková, Mirjam, Bratrské tisky Ivančické a Kralické (Prague, 1951).

Drake Boehm, Barbara and Jiř́ Fajt, eds., Prague. The Crown of Bohemia 1347-1437 (New Haven, 2005).

Hejnic, J. and J. Martínek, eds., Rukovět' humanisticékho básnictví v Čechách a na Moravě, 5 vols. (Prague, 1966-82).

Just, Jiří, “Knižní kultura české reformace," in Umění české reformace (1380-1620), eds.

Kateřina Horníčková and Michal Šroněk (Prague, 2010), pp. 335-354.

Kyas, Vladimír, Česká Bible v dějinách národního písemnictví (Prague, 1997).

Macek, Josef, "Bohemia and Moravia," in The Renaissance in National Context, eds. Roy Porter and Mikuláš Teich (Cambridge, 1992), pp. 197-220.

Mengel, David, “Bones, Stones and Brothels: Religion and Topography in Prague under Emperor Charles IV (1346-78)" (Ph.D., University of Notre Dame, 2003).

Pešek, Jiří, Jiří Melantrich z Aventýna: př́běh pražského arcitiskaře, Slovo k historii 32 (1991).

Říčan, Rudolf, "Tschechische Übersetzungen von Luthers Schriften bis zum. Schmalkaldischen Krieg," in Vierhundertfünfzig Jahre lutherische Reformation, ed. Helmar Junghans (Berlin, 1967), pp. 282-301.

Sixtová, Olga, ed., Hebrew Printing in Bohemia and Moravia (Prague, 2012).

73 Letter of Rimay to Justus Lipsius in Rimay, Összes müvei, p. 223. 
Strupl, Milos, "Confessional Theology of the Unitas Fratrum," Church History 33 (1964), 279-293.

Tobolka, Z., et al., eds., Knihopis českých a slovenských tisků od doby nejstaršíaž do konce 18. století (Prague, 1925-67).

van Dussen, Michael, From England to Bohemia. Heresy and Communication in the Later Middle Ages (Cambridge, 2012).

Veselá-Prudková, Lenka, Židé a česká společnost v zrcadle literatury: od středověku $k$ počátkům emancipace (Prague, 2003).

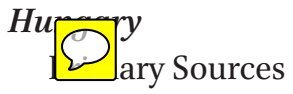

Bibliotheca Hungarica Antiqua 43 vols. (Budapest, 1959-2009).

Balassi, Bálint, Összes müvei 2 vols., ed. Sándor Eckhardt (Budapest, 1951-4).

The Hungarian Reformation Online, adv. ed. Graeme Murdock (Leiden, 2011).

Régi Magyar Költők Tára 12 vols. (Budapest, 1877-2004).

Régi Magyarországi Nyomtatványok 4 vols. (Budapest, 1971-2012).

Répertoire de la poésie hongroise ancienne 2 vols., ed. Iván Horváth (Paris, 1992).

Rimay, János, Összes müvei, ed. Sándor Eckhardt (Budapest, 1955).

Stoll, Béla, A magyar kéziratos énekeskönyvek és versgyüjtemények bibliográfiája: 1542-1840 (Budapest: 2002).

\section{Secondary Literature}

2 a Sacra Hungarica, eds. János Heltai and Botond Gáborjáni Szabó (Budapest, 2008). Biblia Hungarica Philologica, ed. János Heltai (Budapest, 2009).

Ecsedy, Judit V., A könyvnyomtatás Magyarországon a kézisajtó korában: 1473-180o (Budapest, 1999).

Fata, Márta, Gyula Kurucz, and Anton Schindling, eds., Peregrinatio Hungarica: Studenten aus Ungarn an deutschen und österreichischen Hochschulen vom 16. bis zum 20. Jahrhundert (Tübingen, 2006).

Fekete, Csaba, et al., Egyház és müvelódés. Fejezetek a reformátusság és a müvelődés 16-19 századi történetéból, ed. Csaba Fekete (Debrecen, 2000).

Haiman, György, Nicholas Kis. A Hungarian Punch-Cutter and Printer (1650-1702) (San Francisco, 1983).

Heltai, János, and Réka Tasi, eds., "Tenger az igaz hitrül való egyenetlenségekvitatásának eláradott o 2D. Tanulmányok 16-19. századi hitvitáinkról (Miskolc, 2005).

Imre, Mihály, A Vizsolyi Biblia egyikforrása: Petrus Martyr (Debrecen, 2006).

Jankovits, László, and Géza Orlor eds., A magyar irodalom történetei. A kezdetektől 180o-ig (Budapest, 2007).

Latzkovits, Miklós, A drámaírás gyakorlata a 16-17. századi Magyarországon (Budapest, 2007). 
Madas, Edit, and István Monok, A könyvkultúra Magyarországon a kezdetektöl 173o-ig (Budapest, 1998).

Murdock, Graeme, Calvinism on the Frontier, 1600-1660: International Calvinism and the Reformed Church in Hungary and Transylvania (Oxford, 2000).

Nemeskürty, István, Magyar bibliaforditások Hunyadi János korától Pázmány Péter századáig (Budapest, 1990).

Pálffy, Géza, The Kingdom of Hungary and the Habsburg Monarchy in the Sixteenth Century (New York, 2009).

Petrőczi, Éva, and András Szabó, eds., A zsoltár a régi magyar irodalomban (Budapest, 2011).

Szabó, András, Károlyi Gáspár (Budapest, 1982).

Vásárhelyi, Judit P., Szenci Molnár Albert és a Vizsolyi Biblia új kiadásai: előzmények és fogadtatás (Budapest, 2006). 